\title{
ORIGINS OF CHROMIAN AND ALUMINOUS SPINEL MACROCRYSTS FROM KIMBERLITES IN SOUTHERN AFRICA
}

\author{
DANIEL J. SCHULZE $\$$ \\ Department of Geology, University of Toronto, Erindale College, Mississauga, Ontario L5L 1C6, Canada
}

\begin{abstract}
A comparison is made of the major- and minor-element compositions of spinel-group minerals that occur as single-crystal macrocrysts in kimberlites from southern Africa (approximately 1500 grains from 20 kimberlites on the Kaapvaal and Zimbabwe cratons) with those from a variety of mantle xenoliths from southern Africa and North America (approximately 150 xenoliths). Extensive compositional overlap between macrocryst and xenolith samples leads to the conclusion that most macrocrysts of spinel-group minerals are likely to be xenocrysts from garnet-bearing peridotite. None are considered to be igneous phenocrysts related to the host kimberlites. Chromian spinel with $\mathrm{Cr} /(\mathrm{Cr}+\mathrm{Al})>0.88$ is derived from garnet-free assemblages that have bulk $\mathrm{Cr} /(\mathrm{Cr}+\mathrm{Al})$ values too low to form garnet, or from assemblages in which aluminum is partitioned into a different phase, such as metasomatic phlogopite. Such Cr-rich macrocrysts are more common in Group-I kimberlites than in Group-II kimberlites. Moderate degrees of metasomatism produced spinel-group minerals enriched in Fe, Ti and $\mathrm{Cr}$ in many Group-I suites, but chromite xenocrysts from highly metasomatized assemblages (e.g., zircon-bearing) are uncommon. Unusually Fe- and Ni-rich macrocrysts unique to the Lace mine are from Fe-rich orthopyroxene-bearing peridotites or pyroxenites that may be the product of impactinduced mantle melting associated with the Vredefort structure. Regional variations in chemical characteristics of spinel-group minerals suggest that the mantle is more "fertile" [i.e., lower $\mathrm{Cr} /(\mathrm{Cr}+\mathrm{Al})$ values] near craton margins (e.g., Liqhobong on the southeastern margins of the Kaapvaal Craton). Though situated on the Kaapvaal Craton, the Jwaneng suite of "spinel" has chemical characteristics similar to Orapa and Letlhakane suites, which suggests closer affinity to the Zimbabwe cratonic mantle than the Kaapvaal mantle.
\end{abstract}

Keywords: kimberlite, chromian spinel, magnesiochromite, southern Africa.

\section{SOMMAIRE}

Je présente ici une comparaison, en termes des éléments majeurs et mineurs, de la composition des minéraux du groupe du spinelle présents sous forme de macrocristaux uniques dans les kimberlites de l'Afrique australe (environ 1500 grains provenant de vingt kimberlites des cratons de Kaapvaal et de Zimbabwe) avec ceux d'une variété de xénolithes du manteau provenant d'Afrique australe et d'Amérique du Nord (environ 150 xénolithes). Un chevauchement important des populations de macrocristaux et de xénolithes mène à la conclusion que dans la plupart des cas, les macrocristaux de spinelle (sensu lato) seraient des xénocristaux libérés de fragments de péridotite à grenat. Il n'y a pas d'évidence qu'ils pourraient être des phénocristaux issus de la kimberlite hôte. Tout spinelle chromifère ayant un rapport $\mathrm{Cr} /(\mathrm{Cr}+\mathrm{Al})$ supérieur à 0.88 doit être dérivé d'un assemblage sans grenat, où la valeur globale du rapport $\mathrm{Cr} /(\mathrm{Cr}+\mathrm{Al})$ est trop faible pour former un grenat ou bien où l'aluminium est réparti dans une autre phase, par exemple la phlogopite d'origine métasomatique. De tels macrocristaux sont plus répandus parmi les kimberlites du groupe I que dans ceux du groupe II. Une métasomatose de moyenne intensité aurait produit des minéraux du groupe du spinelle enrichis en Fe, Ti et $\mathrm{Cr}$ dans plusieurs suites kimberlitiques de type I, mais les xénocristaux de chromite provenant d'assemblages résultant d'une métasomatose intense, par exemple ceux qui contiennent le zircon, sont plutôt rares. Les macrocristaux inhabituels riches en $\mathrm{Fe}$ et en Ni provenant de la mine Lace semblent uniques; ils se sont formés à partir de péridotites à orthopyroxène ou de pyroxénites qui pourraient bien avoir été produits par fusion due à l'impact qui a causé la structure de Vredefort. Les variations régionales en caractéristiques compositionnelles des minéraux du groupe du spinelle font penser que le manteau est plus "fertile", c'est-à-dire qu'il possède un rapport $\mathrm{Cr} /(\mathrm{Cr}+\mathrm{Al})$ plus faible, près des bordures du craton, par exemple à Liqhobong, le long de la bordure sud-est du craton de Kaapvaal. Quoique situé sur le craton de Kaapvaal, le spinelle de la suite de Jwaneng partage des caratéristiques avec celui des suites d'Orapa et de Letlhakane, ce qui pourrait indiquer une affinité plus grande avec le manteau sous le craton de Zimbabwe qu'avec celui sous le craton de Kaapvaal.

(Traduit par la Rédaction)

Mots-clés: kimberlite, spinelle chromifère, magnésiochromite, Afrique australe.

§ E-mail address: dschulze@credit.erin.utoronto.ca 


\section{INTRODUCTION}

Members of the spinel solid-solution group of minerals are important, though typically minor, constituents of many igneous and metamorphic rocks. As their compositions are controlled by a variety of factors, including temperature and pressure of equilibration, mode, bulk composition and oxygen fugacity, spinel-group minerals are important petrogenetic indicators (e.g., Irvine 1965, 1967, Haggerty 1991, Roeder 1994).

The chemical composition of minerals in the spinel structural group varies considerably. In this paper, the term spinel-group mineral or simply "spinel" refers to any member of this group without specific reference to composition. The term aluminous spinel refers to compositions with $\mathrm{Cr} /(\mathrm{Cr}+\mathrm{Al})<0.50$ (molar), and chromian spinel refers to those with molar $\mathrm{Cr} /(\mathrm{Cr}+\mathrm{Al})$ $>0.50$. Magnesiochromite indicates chromian spinel with molar $\mathrm{Fe}^{2+} /\left(\mathrm{Fe}^{2+}+\mathrm{Mg}\right)<0.50$, and chromite refers to chromian spinel with molar $\mathrm{Fe}^{2+} /\left(\mathrm{Fe}^{2+}+\mathrm{Mg}\right)>$ 0.50 . Spinel indicates aluminous spinel with molar $\mathrm{Fe}^{2+}$ $\left(\mathrm{Fe}^{2+}+\mathrm{Mg}\right)<0.50$.

Aluminous or chromian spinel is a common constituent of mantle peridotites, and is well known as a minor phase in peridotite xenoliths brought to the surface by kimberlites and alkaline volcanic rocks. Coarse single crystals of spinel-group minerals, referred to as macrocrysts (which indicates grains that are coarser than matrix minerals and typically larger than $\sim 0.2 \mathrm{~mm}$ ), occur in such volcanic rocks, and most are probably xenocrysts derived by disaggregation of mantle xenoliths, although a phenocryst origin has been proposed for some (Mitchell \& Clarke 1976, Griffin et al. 1994, Grutter \& Apter 1998). Magnesiochromite also occurs as a mineral inclusion in natural diamond (e.g., Meyer 1987). Compositions of spinel-group macrocrysts have been widely used in exploration for kimberlites and diamond (e.g., Gurney \& Moore 1993, Gurney et al. 1993).

Although a number of investigations have been directed toward kimberlite-derived spinel-group macrocrysts from a variety of perspectives, most have been primarily concerned with the macrocrysts as an indicator of diamond potential (e.g., Daniels \& Gurney 1989, McCallum \& Waldman 1991, Wyatt et al. 1994, Gurney et al. 1993, Fipke et al. 1995). Fewer studies have been directed at relating spinel-group macrocrysts to mantle sources or to understanding them as indicators of mantle processes (e.g., Haggerty 1991, Griffin $e t$ al. 1994, Schulze 1996, Grutter \& Apter 1998). The origin and significance of spinel-group macrocrysts is here approached through an analysis of chromian and aluminous spinels from various kimberlites in southern Africa and a comparison of these populations with spinel-group minerals from mantle xenoliths.

\section{The Dataset}

In this investigation, approximately 1500 chromite macrocrysts from 20 kimberlites in southern Africa were characterized by electron-microprobe analysis. The kimberlites are primarily located on the Kaapvaal Craton, but include two from the Zimbabwe Craton. Kimberlite locations are shown in Figure 1. Eleven are Group-I kimberlites (Bultfontein, Kamfersdam,

TABLE 1. COMPOSITLON OF SPTNEL-GROLP MINERAISS (AND AN ORTHOPYROKENE TNCLLSION) HROM VARIOUS ASSEMELAGES IN THIS STUOY

\begin{tabular}{|c|c|c|c|c|c|c|c|c|c|c|c|c|c|c|}
\hline Sampile & $\mathrm{SiO}_{7}^{*}$ & $\mathrm{TiO}_{1}$ & $\mathrm{Al}_{2} \mathrm{O}_{3}$ & $\mathrm{CT}_{2} \mathrm{O}_{7}$ & FeO & $\mathrm{Fe}_{2} \mathrm{O}_{3}$ & $\mathrm{MnO}$ & $\mathrm{MgO}$ & kíO & $\operatorname{ZnO}$ & $\mathrm{CaO}$ & Total & $\mathrm{er}^{+}$ & $\underline{\underline{t}}^{\dagger}$ \\
\hline 1 & 0.01 & 2.48 & 5.31 & 42.03 & 22.14 & 18.75 & 0.35 & 7.69 & 0.32 & 0.00 & 0,01 & 99.13 & 0.8416 & 0.6178 \\
\hline 2 & 0,08 & 1,07 & 4.02 & 57.08 & 18.85 & 8. 70 & 0.20 & 9.17 & 0.19 & 0.12 & 0.01 & 95.49 & 0.9051 & 0.5358 \\
\hline 3 & 56.94 & 0.04 & 0,41 & 0.78 & 6.37 & H. & 0.14 & 34.19 & 0.14 & n.e. & 0.46 & 99.47 & & \\
\hline 4 & 0.03 & 0.03 & 63.24 & 2,52 & 8.42 & 2.09 & 0.05 & 20.81 & 1.12 & 0.13 & 0.00 & 98.44 & 0.0261 & 0.1851 \\
\hline 5 & 0.04 & 1.48 & 0.90 & 56,10 & 20,02 & $\mid 1 . T \perp$ & 0.42 & 8.11 & 0.15 & 0.11 & 0,00 & 99.03 & 0.9766 & 0.5810 \\
\hline 6 & 0,00 & 6. 18 & 0.70 & 35.21 & 28.85 & 22.84 & 0.37 & 5.20 & 0.12 & 0.00 & 0.000 & 99.47 & 0.9712 & 0.7570 \\
\hline 7 & 0,0, & 0,02 & 65.41 & 2.90 & 3.79 & 1,50 & 0.03 & 24.62 & 0.49 & 0.03 & 0.00 & 98.87 & 00289 & 0.0795 \\
\hline 8 & 0.05 & 0,02 & 31.10 & 39.10 & 10.15 & 1.15 & 0,17 & 17.03 & 0.10 & 0.19 & 0.00 & 9906 & 0.4575 & 0.2508 \\
\hline 9 & 0.90 & 1.40 & 1.57 & 65.11 & 14.78 & 4.02 & 0.29 & 11.76 & 0,10 & 0.12 & 0.00 & 99.14 & 0.9653 & 0.4138 \\
\hline 10 & 0.05 & 2.40 & 5.85 & 60.37 & 11.76 & 3,19 & 0.21 & 14.72 & 0.16 & 0.06 & 0.00 & 98.77 & 0.8737 & 0.3095 \\
\hline 11 & 0.03 & 1.17 & 1.46 & 65.63 & 14,76 & 3,68 & 0.34 & Il L.51 & $0,1]$ & 0.10 & 0.00 & 98.80 & 0.9680 & 0.4185 \\
\hline 12 & 0.01 & 041 & 160 & 68.06 & 12.80 & 3.07 & 0.32 & 12.40 & 0.10 & 0.10 & 0.00 & 98.87 & 0.9662 & 0.3669 \\
\hline
\end{tabular}

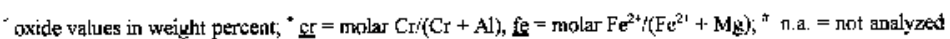
1. Ni-fich chrorite macrosryst, Lace mine (LAC-C1-C3). 2. Chromith macricryat with orthopyroxene irwilusion, Lace

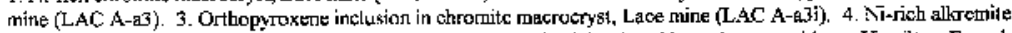
pitul, Kaglvallei mine (13-54-02). 5. Chrotnite from potassic tichterite-phlogopite assemblage Hamilton Eranch

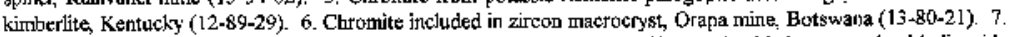

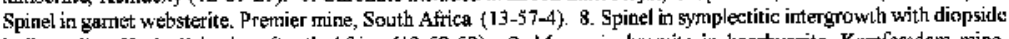

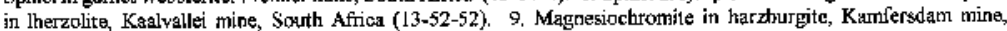

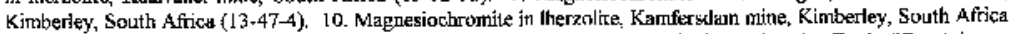

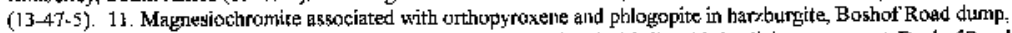
Kimberley, South Afica (13-4 L-26). 12. Magnesiochronite assoctated wich diopsidein olivine megacryst, Boshol Road dump, Kimberley, Suth Africa $(13-41-27)$. 


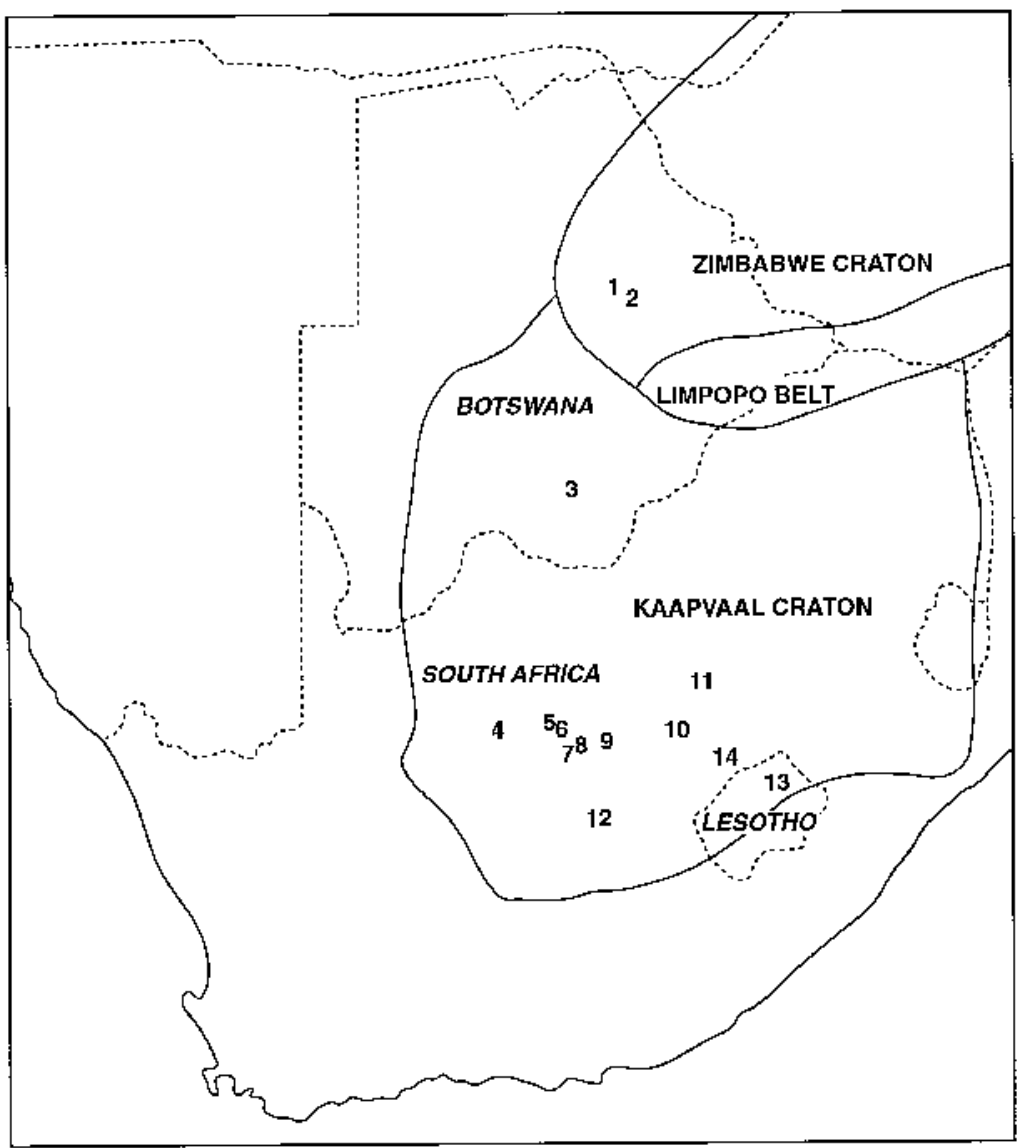

FIG. 1. Locations of kimberlites, sources of the spinel-group macrocrysts in this study, relative to major Archean cratonic units in southern Africa. 1 Orapa, 2 Letlhakane, 3 Jwaneng, 4 Finsch, 5 Bobbejaan, 6 Frank Smith, Balmoral and Eendrag, 7 Bultfontein and Kamfersdam, 8 Loxtonsdal, 9 Blaauwbosch, New Elands and Roberts Victor, 10 Star, 11 Lace, 12 Jagersfontein, 13 Liqhobong and Kao, 14 Monastery. Craton boundaries after de Wit et al. (1992), Carlson et al. (1996) and Ayres et al. (1998).

Jagersfontein, Balmoral, Frank Smith, Monastery in South Africa, Kao and Liqhobong in Lesotho, and Jwaneng, Letlhakane and Orapa in Botswana), and nine are Group-II kimberlites (Finsch, Roberts Victor, Blaauwbosch, New Elands, Bobbejaan, Star, Lace, Eendrag and Loxtonsdal, all in South Africa), with classifications following Smith (1983). (In an alternative scheme of classification, Mitchell (1995) referred to Group-I kimberlites as kimberlites, and Group-II kimberlites as orangeites.) Most macrocrysts were selected from heavy-mineral concentrates in the size range $0.25-2.0 \mathrm{~mm}$ (primarily $0.5-1.0 \mathrm{~mm}$ ), with a few from the Lace mine in the range $3.0-4.0 \mathrm{~mm}$. In addition, approximately 150 ultramafic xenoliths containing spinel-group minerals from kimberlites in southern Af- rica and North America were studied, to provide a database for comparison with spinel-group macrocrysts.

Minerals were analyzed with a Cameca SX-50 electron microprobe at The University of Toronto using standard wavelength-dispersion techniques. Synthetic and natural standards were used, with counting times ranging from $10 \mathrm{~s}$ for major elements to $60 \mathrm{~s}$ for minor elements, such as $\mathrm{Zn}$ and Ni. The data were reduced with PAP correction procedures. Details of the procedure are given in Vicker (1997). The tabulated mineral chemical data can be downloaded from the Internet by connecting to the University of Toronto Department of Geology's WWW server at URL HTTP://www.geology.utoronto. ca. Follow the link to "Software and Data Sets From Our Researchers". Table 1 of this paper contains chemi- 
cal data for spinel-group minerals from a variety of associations in this study.

\section{Summary of Chemical Characteristics OF "SPINEL" MACROCRYSTS}

In Figure 2, populations of "spinel" macrocrysts from kimberlites in this study are shown in terms of their molar $\mathrm{Cr} /(\mathrm{Cr}+\mathrm{Al})$ and $\mathrm{Fe}^{2+} /\left(\mathrm{Fe}^{2+}+\mathrm{Mg}\right)$ values. Calculations of $\mathrm{Fe}^{2+}$ and $\mathrm{Fe}^{3+}$ were based on the constraints of stoichiometry, with formulae normalized to three cations. Although the populations of spinel-group macrocrysts in this study are quite varied (especially in detail), many populations on the Kaapvaal Craton (Group-I kimberlites Bultfontein, Kamfersdam, Jagersfontein, and Group-II kimberlites New Elands, Blaauwbosch, Roberts Victor and Finsch) are dominated by magnesiochromite in the approximate ranges $0.80<$ $\mathrm{Cr} /(\mathrm{Cr}+\mathrm{Al})<0.90$ and $0.30<\mathrm{Fe}^{2+} /\left(\mathrm{Fe}^{2+}+\mathrm{Mg}\right)<0.50$. In the Group-I Orapa and Letlhakane suites on the Zimbabwe Craton in Botswana, the "spinel" populations also correspond to these ranges, but their compositions trend to both more $\mathrm{Fe}$ - and $\mathrm{Cr}$-rich and to more $\mathrm{Mg}$ - and Al-rich values (chromite and spinel, respectively), and the population from the Group-I Frank Smith mine (Kaapvaal Craton) is similar to these, though Frank Smith compositions do not extend into the spinel field. The Group I Jwaneng kimberlite, also in Botswana, but located in the northwestern region of the Kaapvaal Craton, has a macrocryst population that is somewhat similar to those from Orapa and Letlhakane. Suites from the Group-I Liqhobong and Kao kimberlites in Lesotho, on the southeastern margin of the Kaapvaal Craton, and the more centrally located Group-II Loxtonsdal kimberlite, contain many samples with low $\mathrm{Cr} /(\mathrm{Cr}+\mathrm{Al})$ values, similar to the Botswana suites, but these kimberlites lack chromite with elevated $\mathrm{Cr} /(\mathrm{Cr}+\mathrm{Al})$ and $\mathrm{Fe}^{2+} /\left(\mathrm{Fe}^{2+}+\right.$ $\mathrm{Mg}$ ) values.

The chromian spinel populations in four suites (the Group-II Star, Bobbejaan and Lace kimberlites and the Group-I Balmoral kimberlite) have higher average $\mathrm{Fe}^{2+}$ $\left(\mathrm{Fe}^{2+}+\mathrm{Mg}\right)$ values. In the cases of Bobbejaan, Star and Lace, there are significant numbers of grains with $\mathrm{Fe}^{2+}$ / $\left(\mathrm{Fe}^{2+}+\mathrm{Mg}\right)$ above 0.50 . In this regard, these suites are similar to the Botswana examples, but they lack the significant population of Al- and Mg-rich spinel found in the Botswana suites. At Lace, there seems to be a clear bimodal distribution of $\mathrm{Fe}^{2+} /\left(\mathrm{Fe}^{2+}+\mathrm{Mg}\right)$ values, with 37 of 98 grains having $\mathrm{Fe}^{2+} /\left(\mathrm{Fe}^{2+}+\mathrm{Mg}\right)$ greater than 0.50 . There is not a clear separation at Bobbejaan, and too few data exist for Star to comment on their distribution. Although the Balmoral suite contains chromian spinel with a high average $\mathrm{Fe}^{2+} /\left(\mathrm{Fe}^{2+}+\mathrm{Mg}\right)$ value, it does not contain many examples of chromite $\left[\mathrm{Fe}^{2+} /\left(\mathrm{Fe}^{2+}\right.\right.$ $+\mathrm{Mg}$ ) above 0.50], but few of the magnesiochromite compositions have $\mathrm{Fe}^{2+} /\left(\mathrm{Fe}^{2+}+\mathrm{Mg}\right)$ below 0.40 . The composition of a chromite macrocryst with an orthopyroxene inclusion from the Lace suite is given in Table 1.
Aluminous spinel $[\mathrm{Cr} /(\mathrm{Cr}+\mathrm{Al})<0.50]$ is not abundant in any of these kimberlites, but it does occur, and some examples from Jagersfontein and Star are nearly $\mathrm{Cr}$-free. These samples are discussed further below, in terms of their minor-element contents.

In Figure 3, variations in $\mathrm{Ni}$ content $(\mathrm{wt} \% \mathrm{NiO})$ with $\mathrm{Fe}^{2+} /\left(\mathrm{Fe}^{2+}+\mathrm{Mg}\right)$ values are shown. Chromian spinel from Lace is emphasized in this figure; the grains of chromite $\left[\mathrm{Fe}^{2+} /\left(\mathrm{Fe}^{2+}+\mathrm{Mg}\right)>0.50\right]$ are characterized by elevated $\mathrm{Ni}$ values (up to $0.35 \mathrm{wt} \% \mathrm{NiO}$, e.g., Table 1), in contrast to the magnesiochromite group $\left[\mathrm{Fe}^{2+} /\right.$ $\left.\left(\mathrm{Fe}^{2+}+\mathrm{Mg}\right)<0.50\right]$, in which $\mathrm{NiO}$ is less than 0.21 $\mathrm{wt} \%$ ). Enrichment in Ni is not evident in chromite from Group-I kimberlites, and only two such grains of chromite were found in the major Group-II kimberlite population (both from Loxtonsdal). Ni values from chromite at Bobbejaan and Star are also relatively low $(<0.23 \mathrm{wt} \% \mathrm{NiO})$, unlike those at Lace, but similar to Group-I chromite macrocrysts. Ni also correlates positively with calculated $\mathrm{Fe}^{3+}$ in chromite from Lace, indicating presence of the $\mathrm{NiFe}^{3+}{ }_{2} \mathrm{O}_{4}$ spinel component (trevorite).

A few grains of spinel (sensu stricto) from Group-I and Group-II kimberlites have high Ni values (0.39$0.63 \mathrm{wt} \% \mathrm{NiO}$ ) (Fig. 3; four from Jagersfontein, one from Orapa and two from Finsch). These Ni-rich grains have low $\mathrm{Cr} /(\mathrm{Cr}+\mathrm{Al})$ values [most with $\mathrm{Cr} /(\mathrm{Cr}+\mathrm{Al})<$ $0.15]$.

Figure 4 illustrates $\mathrm{TiO}_{2}-\mathrm{NiO}$ relationships in the population of macrocrysts. At Lace, $\mathrm{TiO}_{2}$ does not distinguish chromite from magnesiochromite, as the entire suite varies in Ti from low $\left(<0.5 \mathrm{wt} \% \mathrm{TiO}_{2}\right)$ to high $\left(\sim 3.0 \mathrm{wt} \% \mathrm{TiO}_{2}\right)$, regardless of iron content. Ti-rich chromian spinel $\left(>3.0 \mathrm{wt} \% \mathrm{TiO}_{2}\right)$ is prominent in GroupI kimberlites, a characteristic shown by all the Group-I kimberlites in this study (though not indicated on a pipeby-pipe basis on Fig. 4). In contrast, Ti-rich chromian spinel is not as abundant in most Group-II kimberlites, though all suites in this study have at least some grains with more than $2.0 \mathrm{wt} \% \mathrm{TiO}_{2}$. A few samples from both Group-I and -II kimberlites correspond to the Lace chromite group in terms of $\mathrm{TiO}_{2}-\mathrm{NiO}$ relationships (including the two NiO- and Fe-rich examples from Loxtonsdal, illustrated in Fig. 3, which, at approximately $1 \% \mathrm{TiO}_{2}$, are not unusual). The chromian spinel from Star and Bobbejaan does not appear to resemble chromite from Lace in NiO- $\mathrm{TiO}_{2}$ characteristics, but is similar to other Group-II (and -I) macrocrysts.

$\mathrm{TiO}_{2}-\mathrm{Cr} /(\mathrm{Cr}+\mathrm{Al})$ relations are shown for the macrocrysts in Figure 5. The strong concentration of data points in the range $0.8<\mathrm{Cr} /(\mathrm{Cr}+\mathrm{Al})<0.9$ is evi-

FIG. 2. Molar $\mathrm{Cr} /(\mathrm{Cr}+\mathrm{Al})$ and $\mathrm{Fe}^{2+} /\left(\mathrm{Fe}^{2+}+\mathrm{Mg}\right)$ values of spinel-group minerals occurring as macrocrysts derived from kimberlites in this study. The number next to the name of each kimberlite refers to its location in Figure 1. 

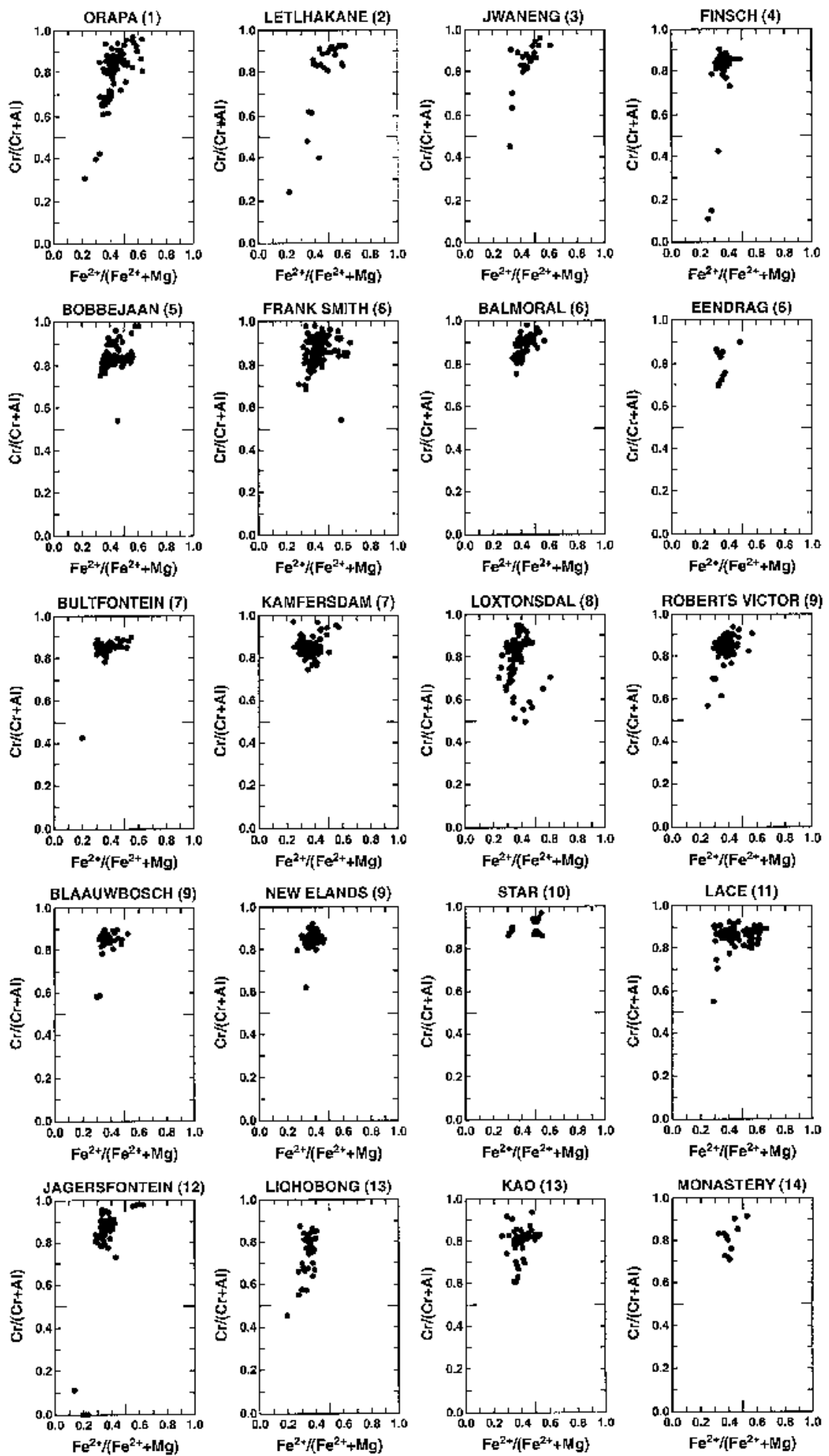

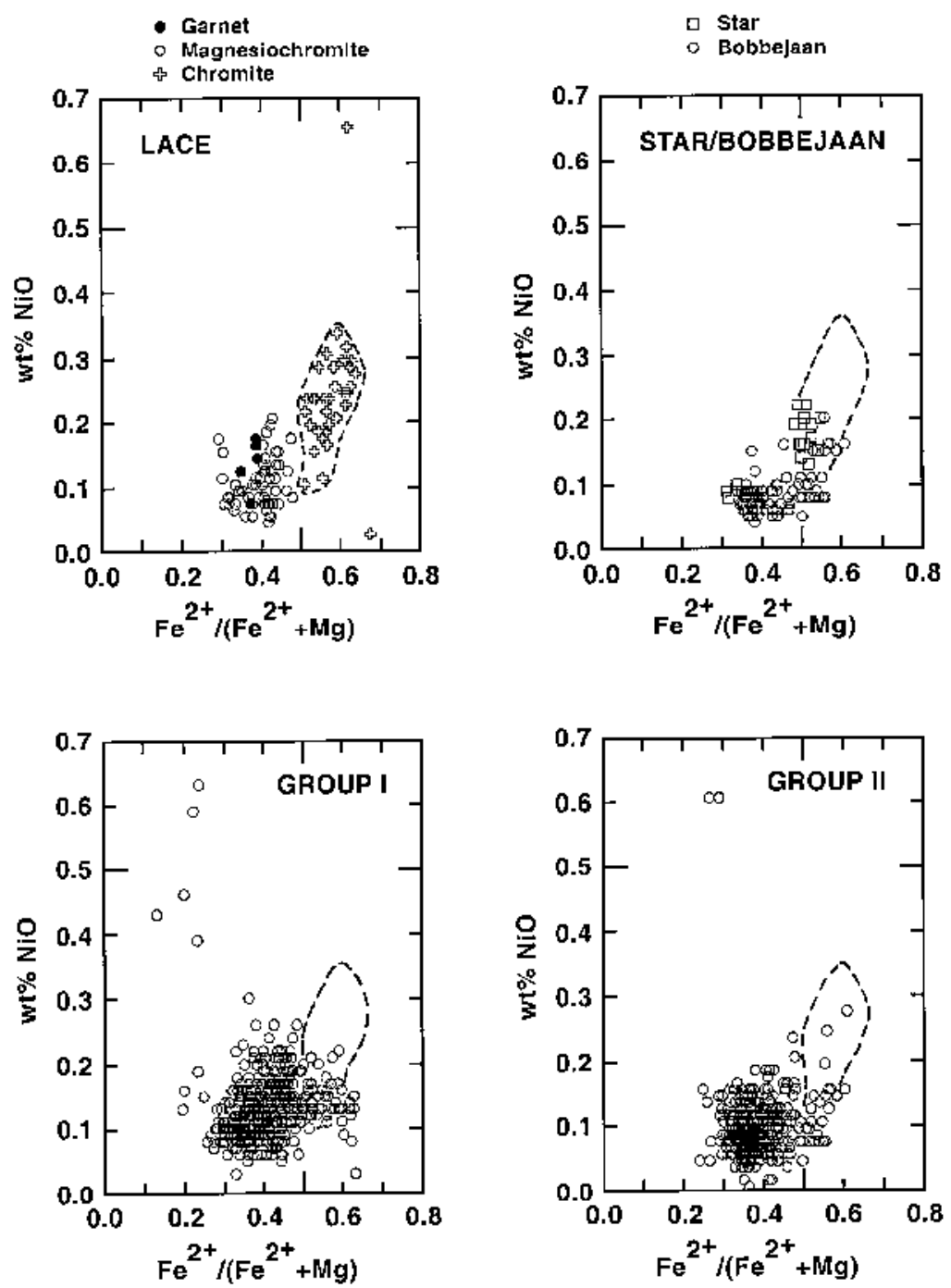

FIG. 3. Variation of Ni with molar $\mathrm{Fe}^{2+} /\left(\mathrm{Fe}^{2+}+\mathrm{Mg}\right)$ in "spinel" macrocrysts in this study. For Lace, symbols designate chromite versus magnesiochromite macrocrysts and those cases of magnesiochromite intergrown with garnet. The compositions of Star and Bobbejaan macrocrysts are distinguished from one another by different symbols. Dashed line outlines the field of chromite macrocrysts at Lace (two grains excluded).

dent for all populations. High-Ti chromian spinel is more prominent in the Group-I suites at high $\mathrm{Cr} /(\mathrm{Cr}+$ $\mathrm{Al})$ values $(>\sim 0.88)$ than in the Group-II population. The cluster of Group-I data near $\mathrm{Cr} /(\mathrm{Cr}+\mathrm{Al})=0.90$ and $\mathrm{TiO}_{2}$ between 3.0 and $3.5 \mathrm{wt} \%$ corresponds to a concentration of data points from Balmoral.

\section{Variations in Macrocryst Size And Shape}

In most suites in this study, "spinel" grains were not characterized by shape prior to preparation of polished sections, although this was done for the Blaauwbosch suite and a follow-up suite from Lace. At Lace, following analysis of a population of 98 randomly selected grains, the shapes of which were not documented, 119 additional grains (representing all "spinels" in a small split of heavy-mineral concentrate) were selected from the 1-2 mm size-range. Of the 55 grains that were classified as anhedral, 20 are chromite and, of the 64 that were classified as euhedral to subhedral, 12 are chromite (Fig. 6). Nine coarse grains of chromian spinel (all anhedral) were recovered from the Lace 3-4 mm frac- 

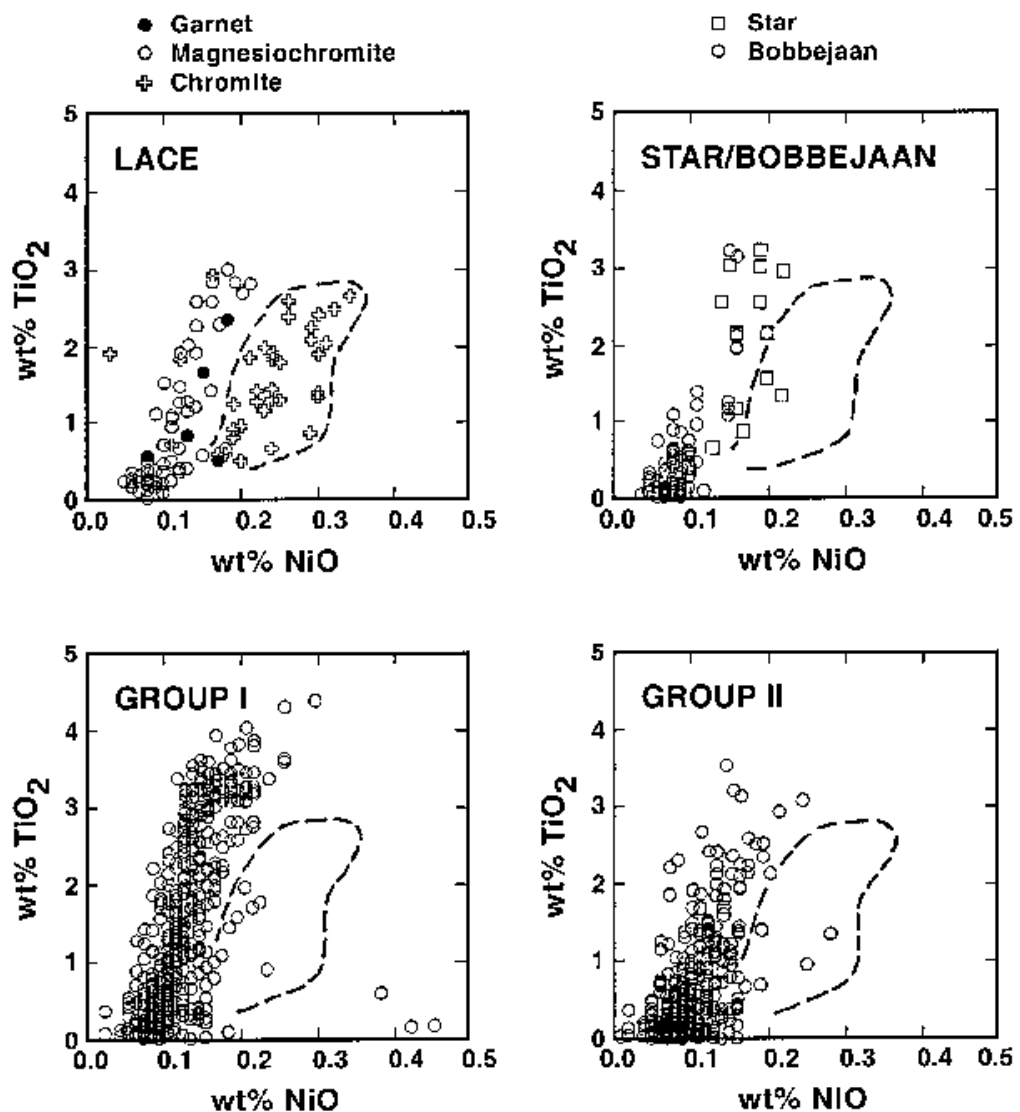

FIG. 4. Ni-Ti variations of "spinel" macrocryst compositions in this study. Some Ni-rich grains from Group-I and -II kimberlites $(\mathrm{NiO}>0.5 \mathrm{wt} \%)$ are not shown.

tion (in which spinel-group minerals are uncommon), four of which are chromite (Fig. 6).

In the Blaauwbosch suite, 20 of 50 grains were classified as euhedral, and the only noticeable relationship between shape and composition is that the two most aluminous compositions $[\mathrm{Cr} /(\mathrm{Cr}+\mathrm{Al}) \approx 0.60$ : Fig. 2] are anhedral. Thus there does not seem to be any discernible relationship between mineral composition and habit in the two suites in which this aspect was examined.

\section{"Spinel” from Mantle Xenoliths}

Figures 7-10 illustrate chemical characteristics of chromian and aluminous spinel from mantle assemblages. Data for 82 of these samples ("spinel" - garnet or "spinel" - pyroxene \pm garnet composite xenocrysts from Kimberley, Lace and Roberts Victor kimberlites and "spinel" \pm garnet peridotites from Jagersfontein and Kimberley) were published by Schulze (1996) and Schulze et al. (1997). These data are supplemented here by results of 73 new analyses of spinel-group minerals from mantle xenoliths from southern African and North American kimberlites, representing a greater range of parageneses of spinel-group minerals from the upper mantle. The data in these figures are heavily weighted toward garnetiferous chromian-spinel-bearing assemblages from Kimberley (Bultfontein and Kamfersdam kimberlites and xenoliths from various tailings dumps in Kimberley), and thus the distribution of data is unlikely to reflect accurately the relative abundances of different "spinel"-bearing rock types in the upper mantle. The range of rock types is broad, however, and includes garnet-bearing and garnet-free peridotites (lherzolite, wehrlite, harzburgite, dunite) from $\mathrm{Cr}$-rich to Al-rich examples, representing a variety of locations in North America and southern Africa. Also included are PKP (phlogopite - potassic richterite peridotite) assemblages (a Kimberley phlogopite - potassic richterite peridotite, a Bultfontein LIMA [lindsleyite-mathiasite]bearing assemblage and a potassic richterite - phlogo- 

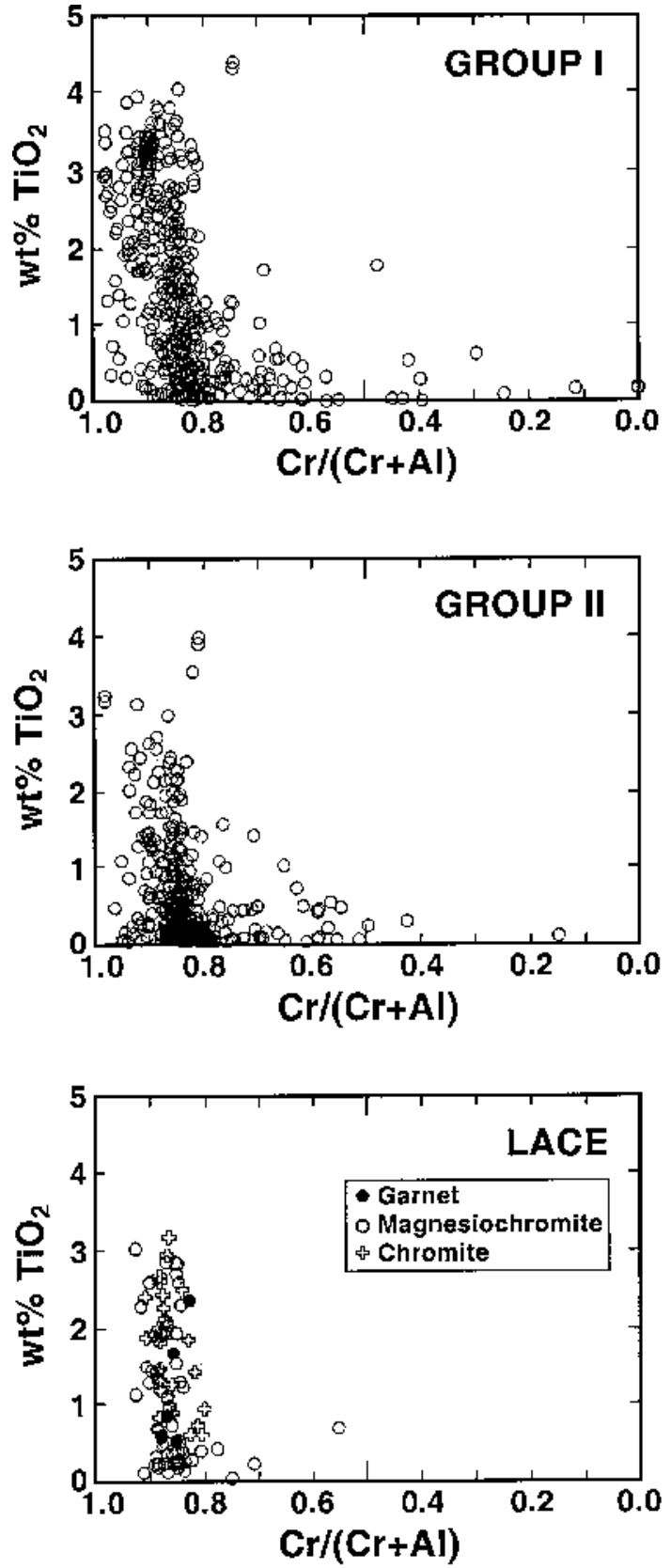

FIG. 5. $\mathrm{Ti}-\mathrm{Cr} /(\mathrm{Cr}+\mathrm{Al})$ relationships of "spinel" macrocrysts. Group II here includes Star and Bobbejaan samples. One Ti-rich macrocryst from Lace $\left(>8 \% \mathrm{TiO}_{2}\right)$ is not shown.

pite - chromite xenolith from Hamilton Branch, Kentucky), garnet - spinel websterite from Premier, South Africa and Sloan, U.S.A., alkremites (garnet-spinel

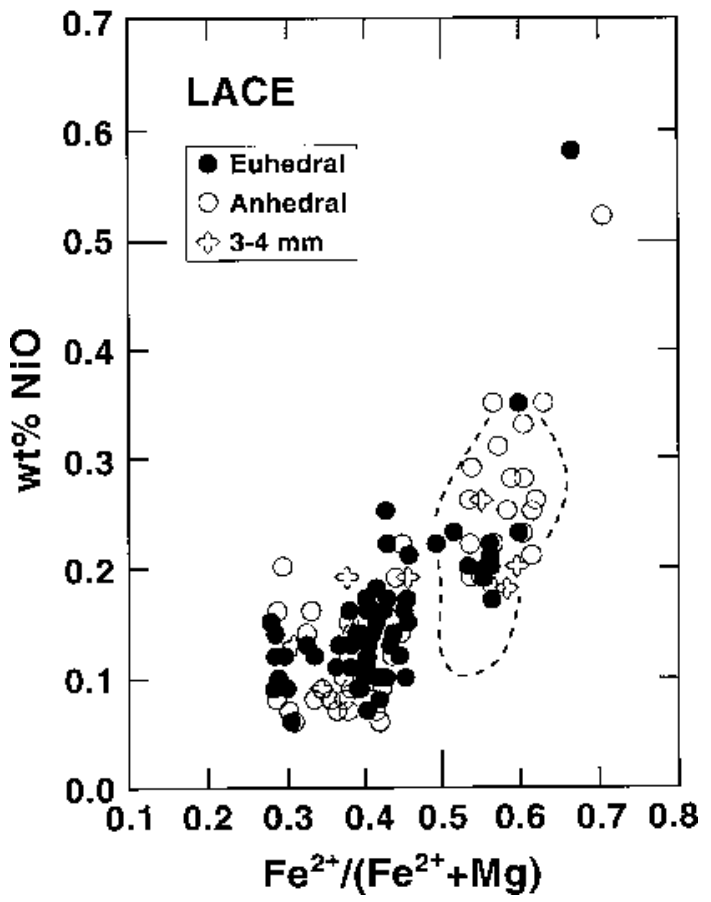

FIG. 6. $\mathrm{Ni}-\mathrm{Fe}^{2+} /\left(\mathrm{Fe}^{2+}+\mathrm{Mg}\right)$ relationships in Lace macrocrysts, categorized by size and shape. Circles represent grains from the 1-2 mm size fraction (55 anhedral grains and 64 euhedral to subhedral grains). Eleven grains from the $3-4 \mathrm{~mm}$ fraction are all anhedral. Dashed line encloses the field of chromite at Lace, taken from Figure 3.

rocks) from Kaalvallei, Roberts Victor and Jagersfontein, South Africa, and chromite-bearing zircon xenocrysts from Orapa, Botswana (likely xenocrysts from highly metasomatized peridotites or MARID [mica - amphibole - rutile - ilmenite - diopside] rocks). This petrologically and geographically diverse suite of xenoliths may give a reasonable picture of the range of compositional variations expected of spinel-group minerals in different mantle assemblages. Table 1 contains compositions of spinel-group minerals from a selection of these samples.

Figure 7 illustrates $\mathrm{Cr} /(\mathrm{Cr}+\mathrm{Al})$ and $\mathrm{Fe}^{2+} /\left(\mathrm{Fe}^{2+}+\right.$ $\mathrm{Mg}$ ) values of chromian and aluminous spinels from these various mantle assemblages. Spinel compositions from some garnet-bearing assemblages extend to extremely low $\mathrm{Cr}$ contents, such as those from the alkremites and a Premier websterite with $\mathrm{Cr} /(\mathrm{Cr}+\mathrm{Al})$ in the range 0.004 to 0.029 (e.g., Table 1). The composition of spinel-group minerals from garnet-bearing peridotite assemblages spans the $\mathrm{Cr} /(\mathrm{Cr}+\mathrm{Al})$ range from 0.116 to 0.876 . That from garnet-free peridotite ranges from similarly low values of $\mathrm{Cr} /(\mathrm{Cr}+\mathrm{Al})(0.098)$ to $\mathrm{Cr} /(\mathrm{Cr}+\mathrm{Al})$ values much higher than those from 


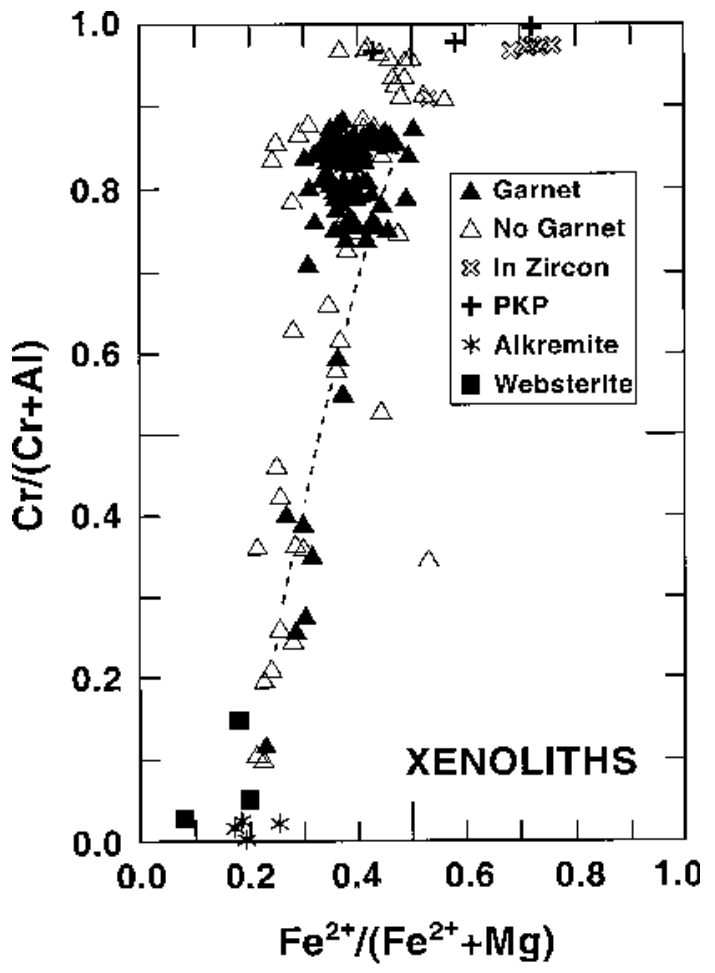

FIG. 7. $\mathrm{Cr} /(\mathrm{Cr}+\mathrm{Al})-\mathrm{Fe}^{2+} /\left(\mathrm{Fe}^{2+}+\mathrm{Mg}\right)$ relationships of spinel-group minerals from ultramafic xenoliths in this study. Peridotites are subdivided into garnet-bearing and garnet-free varieties. The PKP association indicates chromian spinel from assemblages that contain potassic richterite. The dashed line represents the range of "spinel" compositions calculated by Roeder (1994) to be in equilibrium with olivine $\left(\mathrm{Fo}_{90}\right)$ at $1000^{\circ} \mathrm{C}$.

garnetiferous assemblages (to 0.968). A diverse group of rock types is represented by chromian spinel with $\mathrm{Cr} /$ $(\mathrm{Cr}+\mathrm{Al})>0.88$, including peridotites (harzburgite, lherzolite and wehrlite) that lack phlogopite as well as mica-bearing varieties. The most extreme $\mathrm{Cr} /(\mathrm{Cr}+\mathrm{Al})$ values are from chromite and magnesiochromite in metasomatized potassic-richterite-bearing peridotites (the PKP rocks of Erlank et al. 1987) and chromite included in zircon from Orapa, in which $\mathrm{Cr} /(\mathrm{Cr}+\mathrm{Al})$ values reach 0.995 (e.g., Table 1).

Also shown in Figure 7 is the range of "spinel" compositions that would be in equilibrium with forsteritic olivine $\left(\mathrm{Fo}_{90}\right)$ at $1000^{\circ} \mathrm{C}$, as calculated by Roeder (1994), which is consistent with spinel-group mineral compositions in the "olivine-spinel mantle array" of Arai (1994). A more magnesian bulk-composition (e.g., olivine with Fo > 90) or a higher temperature of equilibration, or both, would shift equilibrium compositions of spinel-group minerals to more magnesian values than the line in Figure 7.

Comparison of $\mathrm{NiO}-\mathrm{Fe}^{2+} /\left(\mathrm{Fe}^{2+}+\mathrm{Mg}\right)$ and $\mathrm{TiO}_{2}-$ $\mathrm{NiO}$ relations of spinel-group macrocryst populations in Group-I and -II kimberlites, illustrated in Figures 3 and 4, with "spinel" from mantle xenoliths (Figs. 8, 9) shows that the vast majority of the macrocrysts have compositions matched by spinel-group minerals from peridotites. The chromian spinel macrocrysts from the Lace magnesiochromite group and from Star and Bobbejaan are also reasonably well-matched by "spinel" from peridotites. Some Bobbejaan macrocrysts have slightly lower Ni contents at slightly more Fe-rich compositions than chromian spinel in peridotite, but the difference is small (Fig. 8).

Most of the chromite (sensu stricto) macrocrysts from Lace are not matched by chromian spinel from the mantle xenoliths in this study. The chromite data in the Lace suite extend to significantly higher $\mathrm{NiO}$ values at high Fe-contents (Figs. 3, 8), and there is little overlap between the two populations in $\mathrm{TiO}_{2}-\mathrm{NiO}$ space (Fig. 9). The two cases of chromian spinel from peri-

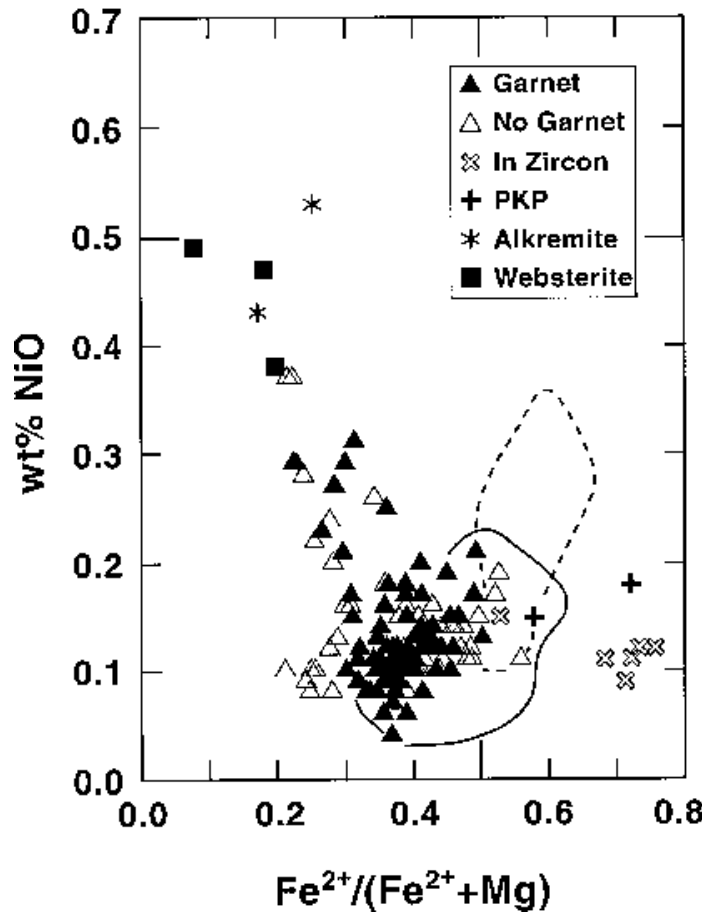

FIG. 8. $\mathrm{Ni}-\mathrm{Fe}^{2+} /\left(\mathrm{Fe}^{2+}+\mathrm{Mg}\right)$ relationships in spinel-group minerals from mantle xenoliths. Dashed line outlines the field of anomalous chromite macrocrysts from Lace, and the solid line outlines the field of chromian spinel macrocrysts from Star and Bobbejaan. Two compositions of alkremite-derived spinel with $\mathrm{NiO}>1.0 \mathrm{wt} \%$ are not shown. 
dotite that do apparently overlap with the chromite from the Lace suite in this diagram are not as Fe-rich $\left[\mathrm{Fe}^{2+} /\right.$ $\left.\left(\mathrm{Fe}^{2+}+\mathrm{Mg}\right)=0.31,0.34\right]$ and thus do not correspond to the chromite at Lace.

A subset of spinel-group minerals in xenoliths, with approximately $0.2-0.4 \mathrm{wt} \% \mathrm{NiO}$ and $0.2<\mathrm{Fe}^{2+} /\left(\mathrm{Fe}^{2+}+\right.$ $\mathrm{Mg})<0.4$, has few equivalents in the macrocryst suite (cf. Figs. 4, 8). These xenolith grains are dominantly spinel (sensu stricto), which are more aluminous than most of the macrocryst grains ( $c f$. Figs. 2, 6), and generally lower in Ti. The chromian spinel in the xenoliths have a wide range of Ti values (Fig. 10).

Several macrocrysts are enriched in $\mathrm{Ni}(0.39-0.63$ wt $\% \mathrm{NiO})$ at low iron contents $\left[\mathrm{Fe}^{2+} /\left(\mathrm{Fe}^{2+}+\mathrm{Mg}\right)<\right.$ 0.30 ] in Figure 3. These are similar to spinel compositions in alkremite and garnet websterite xenoliths (Fig. 8 and Mazzone \& Haggerty 1989), and those from alkremite from Kaalvallei (Table 1) extend to even higher $\mathrm{Ni}$ values (to $1.1 \mathrm{wt} \% \mathrm{NiO}$ ).

\section{DisCUSSION}

\section{Peridotite sources}

The vast majority of "spinel" macrocrysts from both Group-I and Group-II kimberlites in southern Africa analyzed in this study have major- and minor-element

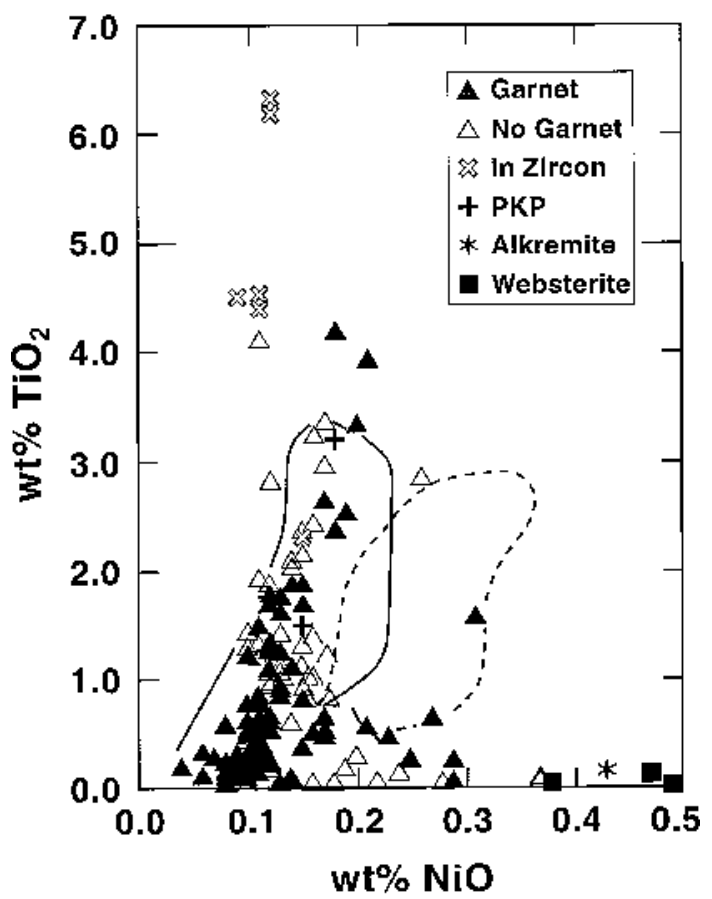

FIG. 9. Ti - Ni relationships in spinel-group minerals from mantle xenoliths. Fields outlined are as in Figure 8. concentrations equivalent to spinel-group minerals in peridotite xenoliths, indicating that the macrocrysts are likely xenocrysts derived by disaggregation of such peridotites during incorporation of xenoliths and ascent and eruption of the kimberlite host. As there is extensive overlap in the compositional characteristics of spinelgroup minerals from garnet-bearing and garnet-free peridotites evaluated in this study, at $\mathrm{Cr} /(\mathrm{Cr}+\mathrm{Al})$ values of "spinel" between approximately 0.12 and 0.88 , macrocrysts in this range cannot be assigned with confidence to origins in garnet-bearing or garnet-free associations.

The distribution of $\mathrm{Cr}$ and $\mathrm{Al}$ between garnet and spinel-group minerals is pressure- and temperature-dependent (e.g., O'Neill 1981, Brey et al. 1991). The maximum $\mathrm{Cr} /(\mathrm{Cr}+\mathrm{Al})$ value of chromian spinel coexisting with garnet in this study, 0.88 , is approximately that predicted from the experimental work of Doroshev et al. (1997) and Girnis \& Brey (1999) for peridotitic assemblages equilibrated on a conductive subcratonic geothermal gradient at pressures of about 55-60 kbar. These conditions correspond to the maximum depth of origin of garnet peridotite xenoliths from a variety of kimberlites in southern Africa and North America, approximately 150-200 kilometers (e.g., Finnerty \& Boyd 1987). The examples of chromian spinel in peridotite in this study that have $\mathrm{Cr} /(\mathrm{Cr}+\mathrm{Al})$ greater than 0.88 are, therefore, not likely to have formed in equilibrium with garnet. If these chromian-spinel-bearing assemblages have equilibrated under approximately the same pressure and temperature conditions as the garnet-bearing peridotites, the absence of garnet can be explained by chromian spinel crystallizing in bulk-rock compositions too low in aluminum [i.e., high $\mathrm{Cr} /(\mathrm{Cr}+\mathrm{Al})$ values] to allow garnet to form, or by partitioning of aluminum into other phases, such as phlogopite (e.g., Boyd et al. 1999). Both of these explanations probably apply to

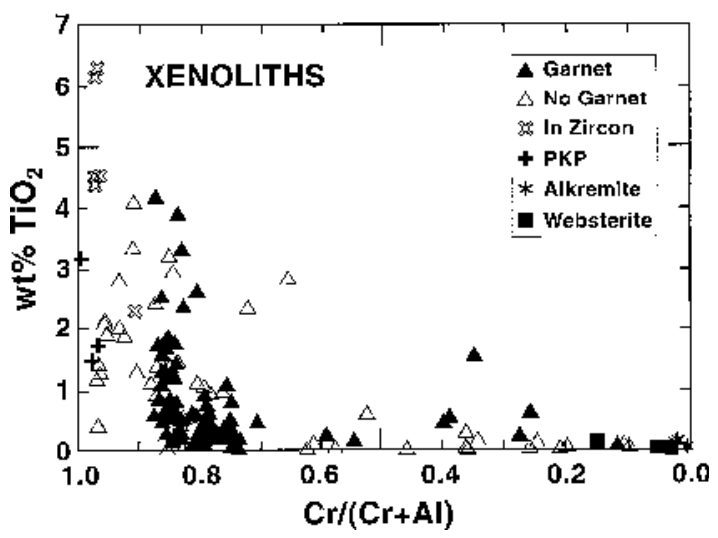

FIG. 10. $\mathrm{Ti}-\mathrm{Cr} /(\mathrm{Cr}+\mathrm{Al})$ relationships of compositions of spinel-group minerals from xenoliths in this study. 
peridotites with a $\mathrm{Cr}$-rich $[\mathrm{Cr} /(\mathrm{Cr}+\mathrm{Al})>0.88]$ spinelgroup mineral in this study (lherzolite, harzburgite and wehrlite), as some examples contain abundant phlogopite, whereas others appear to be phlogopite-free. Chromian spinel associated with zircon and potassic richterite has the highest $\mathrm{Cr} /(\mathrm{Cr}+\mathrm{Al})$ in this study, and these samples are discussed below.

$\mathrm{The} \mathrm{Cr} /(\mathrm{Cr}+\mathrm{Al})$ value of approximately 0.88 is of fundamental importance in the population of samples in this study (both xenoliths and macrocrysts). As discussed above, in the xenolith population, chromian spinel with $\mathrm{Cr} /(\mathrm{Cr}+\mathrm{Al})$ greater than 0.88 does not coexist with garnet (Figs. 7, 10). In the macrocryst populations, there is a large decrease in the number of compositions having $\mathrm{Cr} /(\mathrm{Cr}+\mathrm{Al})$ exceeding 0.88 (especially well illustrated in Fig. 5), particularly in the Group-II macrocryst populations, including both types of chromian spinel from Lace. This is also evident in the Group-I macrocryst population, but less dramatically so, and many of the Group-I macrocrysts with $\mathrm{Cr} /(\mathrm{Cr}+$ $\mathrm{Al}$ ) greater than 0.88 are enriched in $\mathrm{Ti}$ (Fig. 5). Although spinel-group minerals with $\mathrm{Cr} /(\mathrm{Cr}+\mathrm{Al})$ values below 0.88 can exist in the absence of garnet, the distribution of $\mathrm{Cr} /(\mathrm{Cr}+\mathrm{Al})$ values (dominantly in the range $0.80-0.88$ ) in macrocrysts suggests that the bulk of them coexisted with garnet prior to disaggregation.

Relatively aluminous spinel compositions [e.g., $\mathrm{Cr} /$ $(\mathrm{Cr}+\mathrm{Al})<0.60]$ appear to be more common in the xenolith suite (Fig. 7) than among the macrocryst population (Fig. 2). Although peridotites that contain such spinel-group minerals are fairly common in xenolith suites from kimberlites in southern Africa (e.g., Carswell et al. 1979, 1984, Hervig et al. 1980), in many examples the "spinel" grains occur in a symplectitic intergrowth with pyroxene (e.g., Dawson \& Smith 1975, Boyd et al. 1999). The spinel component of these intergrowths is only tens of micrometers in thickness in many cases, and thus may not occur in the heavy-mineral concentrates in the size range examined in this study $(>0.25 \mathrm{~mm})$. Furthermore, a significant number of xenolith samples in this study are from North American kimberlites (e.g., 14 samples from Sloan, Colorado), and the mantle sampled by these kimberlites may be, on average, more aluminous than the mantle sampled by southern African kimberlites in this study. The vast majority of spinel-group samples from peridotites in the Colorado-Wyoming kimberlite province, for example, have $\mathrm{Cr} /(\mathrm{Cr}+\mathrm{Al})$ less than 0.50 (Eggler et al. 1987a).

\section{Zircon and PKP (extreme metasomatic) sources}

In terms of $\mathrm{Cr} /(\mathrm{Cr}+\mathrm{Al})$ values, the most strongly depleted compositions of chromian spinel are those included in zircon from the Orapa mine and the PKP-related assemblages from Kimberley and Kentucky, referred to here as the "extreme metasomatic" suite. Although compositions of the chromian spinel from the Bultfontein LIMA-bearing assemblage and from one of the Orapa zircon crystals overlap the compositional fields of chromian spinel from typical garnet-free peridotite assemblages (Fig. 7), the most extreme metasomatic compositions fall beyond the range of chromian spinel from the other types of xenoliths (Figs. 6-8). They are Fe- and Ti-rich $\left[0.68<\mathrm{Fe}^{2+} /\left(\mathrm{Fe}^{2+}+\mathrm{Mg}\right)<\right.$ 0.76 for four of five grains in zircon], and Ti values range to $6.3 \mathrm{wt} \% \mathrm{TiO}_{2}$ (Fig. 9).

Only one chromite macrocryst in this study, from Lace, which is $\mathrm{Fe}$ - and Ti-rich $\left[\mathrm{Fe}^{2+} /\left(\mathrm{Fe}^{2+}+\mathrm{Mg}\right)=\right.$ $0.641,8.33 \mathrm{wt} \% \mathrm{TiO}_{2}$, and off scale in Fig. 4] and Nipoor (Fig. 3), and thus apparently not part of the Lace Fe-rich suite, is similar to chromite derived from zircon and PKP from the extreme metasomatic suite. Two other Lace samples, although with high $\mathrm{Fe}^{2+} /\left(\mathrm{Fe}^{2+}+\mathrm{Mg}\right)$ values (0.66-0.70: Fig. 6) are Ni-rich extensions of the unusual Lace chromite suite, and not similar to chromite from the extreme metasomatic assemblages. Even at Orapa and the Kimberley pipes, where the zircon-hosted and PKP-xenolith-hosted samples of chromian spinel occur in relative abundance, no chromite macrocrysts corresponding to the extreme metasomatic type have been observed. The extreme metasomatic type of chromite is, therefore, not a significant contributor to the macrocryst populations in the southern African kimberlites in this study.

A number of macrocrysts have compositional characteristics that are intermediate between those in the peridotites xenoliths in this study and those of the extreme metasomatic assemblages, such as some Ti-rich chromite (sensu stricto) from Orapa, Jwaneng, Balmoral, Frank Smith, Jagersfontein and the Kimberley pipes (Fig. 2). In addition to the presence of the PKP-hosted and zircon-hosted assemblages, other metasomatic assemblages, such as chromian and niobian rutile + ilmenite have been described in xenoliths from most of these locations (e.g., Haggerty 1983, Tollo \& Haggerty 1987, Schulze 1990). The Fe-, Ti- and Cr-rich macrocrysts may be derived from metasomatic assemblages not present in the xenolith population in this study.

\section{Low-Cr peridotite and alkremite sources}

Spinel (sensu stricto) macrocrysts are not common in the populations in this study. Only 16 grains out of approximately 1300 have $\mathrm{Cr} /(\mathrm{Cr}+\mathrm{Al})$ values below 0.50 , for example. $\mathrm{NiO}-\mathrm{Cr} /(\mathrm{Cr}+\mathrm{Al})$ relations of these relatively aluminous macrocrysts are compared to spinel from xenoliths in Figure 11. Spinel from garnet-bearing or garnet-free peridotite matches well most of the macrocrysts in this range. The most Cr-poor macrocrysts, such as those from Star and Jagersfontein, with $\mathrm{Cr} /(\mathrm{Cr}+\mathrm{Al})<0.02$, may be xenocrysts derived from pyroxenites or alkremites. No macrocrysts in this study have the very high $\mathrm{Ni}$ contents $(>1.0 \mathrm{wt} \% \mathrm{NiO})$ characteristic of the spinel from alkremite found at Kaalvallei (Fig. 11). 


\section{Sources of chromian spinel at the Lace mine}

There are two distinctly different suites of chromian spinel macrocrysts at the Lace mine. Magnesiochromite compositions $\left[\mathrm{Fe}^{2+} /\left(\mathrm{Fe}^{2+}+\mathrm{Mg}\right)<0.50\right]$ are similar to most other macrocrysts interpreted as xenocrysts from peridotites (dominantly garnet-bearing) in this study. Unlike all other macrocrysts considered, however, a significant number at Lace have $\mathrm{Fe}^{2+} /\left(\mathrm{Fe}^{2+}+\mathrm{Mg}\right)>0.50$ at $\mathrm{Cr} /(\mathrm{Cr}+\mathrm{Al})<0.90$ (Figs. 2, 6). Most of the chromite at Lace is also richer in Ni than most of the chromite macrocrysts or chromite in peridotite xenoliths from other localities, and these two chemical characteristics mark the Lace chromite suite as unique in southern Africa. A few of the chromite grains at Lace have low $\mathrm{Ni}$ contents (Fig. 4), and may be simply more Fe-rich "ordinary" chromian spinel, such as some of the Fe-rich, $\mathrm{Ni}$-poor grains from Orapa, Letlhakane, Bultfontein and Jwaneng.

Only one of the unusual Ni-rich chromite macrocrysts from Lace contains a silicate inclusion that helps to constrain the origin of this suite. Sample LACA-a3, an anhedral grain, contains a single inclusion of orthopyroxene with $\mathrm{Ca} /(\mathrm{Ca}+\mathrm{Mg})=0.010$ and $\mathrm{Mg} /(\mathrm{Mg}$ $+\mathrm{Fe})(m g)=0.905$ (Table 1). It cannot be demonstrated that this orthopyroxene equilibrated with garnet, and determination of its equilibration conditions is restricted to estimating the temperature of formation using pyroxene thermometry. Single-pyroxene thermobarometry (cf. Boyd \& Nixon 1973) using the Finnerty \& Boyd

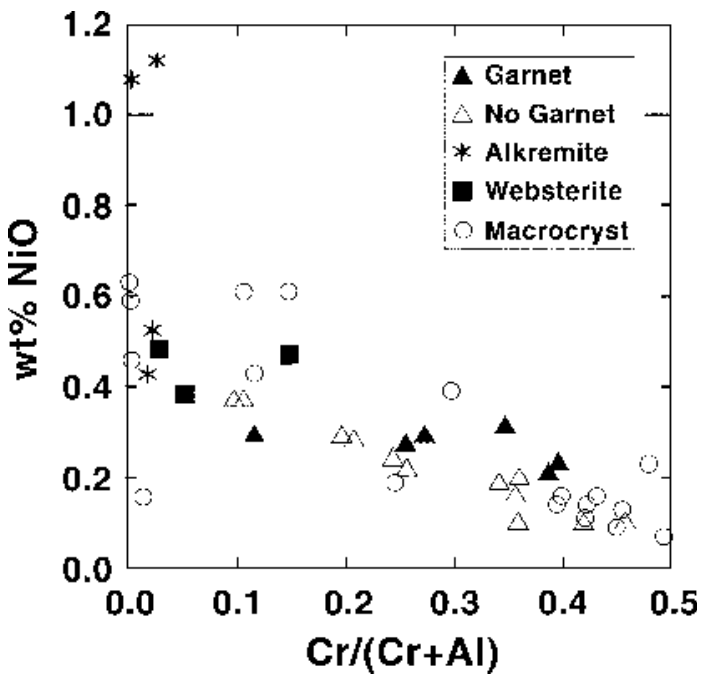

FIG. 11. $\mathrm{Ni}-\mathrm{Cr} /(\mathrm{Cr}+\mathrm{Al})$ relationships of spinel (sensu stricto) compositions from xenoliths and macrocrysts in this study.
(1987) pyroxene thermometer yields a temperature of approximately $1050^{\circ} \mathrm{C}$. If this pyroxene equilibrated on a typical cratonic geothermal gradient, this temperature would correspond to a depth of approximately 150 kilometers, well within the stability field of garnet, but this estimate has large uncertainties associated with it.

Although a mantle origin for the Ni-rich chromite suite from of Lace is suggested by the conditions of equilibration outlined above, the paragenesis is poorly constrained, and such chromite could be derived from a variety of peridotites or pyroxenites. The presence of the orthopyroxene with $m g=0.905$ is consistent with a peridotite assemblage slightly more Fe-rich than typical mantle peridotite. For example, at Kimberley, garnet lherzolites (Boyd \& Nixon 1978) contain olivine $(0.91<m g<0.94)$ that coexists with orthopyroxene $(0.92<m g<0.95)$. Peridotite xenoliths that could aid in understanding the origin of the Ni-rich chromite suite are not known from the Lace kimberlite; high-pressure xenoliths at Lace are dominated by mantle-derived $\mathrm{Cr}$ poor garnet megacrysts and eclogites, as well as garnet granulites of lower crust origin (Schulze \& Helmstaedt 1988). The absence of xenoliths with chromite similar to the Lace Ni-rich chromite suite in other kimberlites, and the apparent virtual absence of such chromite among macrocrysts from other southern African kimberlites, suggest that anomalously Fe-rich peridotite or pyroxenite occurs in the mantle below the Lace kimberlite, and not in other regions of the southern African mantle.

Results of $\mathrm{U} / \mathrm{Pb}$ dating of zircon extracted from mafic garnet granulite xenoliths (lower crust) from Lace indicate high-temperature recrystallization coincident with the nearby $2020 \pm 3$ Ma Vredefort impact (Moser 1997, Moser \& Hart 1998). Taken together with evidence for impact-triggered basaltic magmatism near the center of the eroded crater, it may be that effects of the Vredefort meteorite impact event extended through the lithosphere (Moser et al. 1999). Thus, it is possible that the geochemical anomaly indicated by the Ni-rich chromite macrocrysts of the Lace suite may be related to Vredefort impact-related processes that extended to depths of at least 150 kilometers, explaining the apparent uniqueness of this composition of chromian spinel in southern Africa.

\section{Chromite macrocrysts as kimberlite phenocrysts?}

Several investigators have suggested that at least some macrocrysts of chromian spinel from kimberlite are genetically related to their host kimberlitic magmas (e.g., Mitchell \& Clarke 1976, Griffin et al. 1994, Grutter \& Apter 1998). Macrocrysts of aluminian magnesiochromite have been interpreted by Mitchell \& Clarke (1976) as phenocrysts formed in the early stages of kimberlite crystallization. Although small euhedra of "spinel" of identical composition occur in matrix olivine in some kimberlites, and thus may be genetically 
related to the kimberlite host, the compositional trends of these "spinels" (small euhedra and macrocrysts) in terms of $\mathrm{Cr} /(\mathrm{Cr}+\mathrm{Al})$ and $\mathrm{Fe}^{2+} /\left(\mathrm{Fe}^{2+}+\mathrm{Mg}\right)$ is identical to that of spinel-group minerals from xenoliths in this study (Fig. 7). The relatively large macrocrysts of this composition are interpreted as originating as xenocrysts from mantle peridotites, and a phenocryst model is not needed to explain the macrocryst data.

Griffin et al. (1994) suggested that some macrocrysts of chromian spinel, characterized by elevated $\mathrm{Ti}$ and $\mathrm{Ni}$ contents, among other chemical variables, are phenocrysts from early stages of crystallization of Group-II kimberlite. Schulze (1996) showed that compositions of chromian spinel from various xenoliths match such characteristics, however, and in the present study, most of the chromite macrocrysts have been shown to have compositional and physical characteristics consistent with a mantle xenocryst origin. A few examples of chromian spinel from Bobbejaan and Star exhibit minor chemical differences from the xenolith population of chromian spinel (and in fact these grains are lower in $\mathrm{Ni}$ than those that match well the chromite from xenoliths), but these small differences are not considered significant. All the chromite in the Star and Bobbejaan kimberlites is considered to be xenocrystic.

Grutter \& Apter (1998) proposed that some relatively Ti-rich chromite macrocrysts are of magmatic origin. They suggested that chromian spinel with $\mathrm{Cr}$ contents higher than those coexisting with garnet "cannot be derived from mantle peridotite" and are "early magmatic phenocrysts that crystallize from their host" (Grutter \& Apter 1998). They presented their chromite data on plots of wt $\% \mathrm{Cr}_{2} \mathrm{O}_{3}$ versus $\mathrm{wt} \% \mathrm{TiO}_{2}$, and labeled the sloping field of compositions of chromite coexisting with garnet "MAXCR". In Figure 12, compositions of chromian spinel from xenoliths in this study are plotted on such a diagram. The MAXCR field of Grutter \& Apter (1998) corresponds well with the compositions of chromian spinel in garnet-bearing assemblages, but several compositions of chromian spinel from garnet-free peridotites lie above the MAXCR line (Fig. 12). Several of those samples are composite pyroxene - chromian spinel grains from Kimberley. Although they probably are peridotite xenocryst assemblages, they could conceivably have a variety of origins. Others, however, are chromian spinel from various types of peridotite xenoliths (Table 1). These include harzburgite 13-47-4 and lherzolite 13-47-5 (both of which are phlogopite-poor to phlogopite-free) in which the chromian spinel grains are randomly distributed, as well as examples in which grains of chromian spinel are preferentially associated with pyroxene or phlogopite or both. The latter include a harzburgite with chromian spinel - orthopyroxene - phlogopite clusters (13-41-26) and a 10-cm megacryst of olivine in which chromian spinel is spatially associated with clinopyroxene (13-41-27). Thus, it is clear that chromian spinel with $\mathrm{Cr}$ contents above MAXCR can be derived by disaggregation of mantle peridotite, and need not be considered magmatic.

\section{Regional variations in chromian spinel populations}

Although there is substantial compositional variation in populations of spinel-group minerals from the kimberlites in this study, there are relationships between chemical characteristics and geographic or tectonic setting. Most "spinel" populations from the main cluster of kimberlites in the southwestern regions of the Kaapvaal Craton in Figure 1 (Kamfersdam, Bultfontein, Blaauwbosch, New Elands, Roberts Victor, Jagersfontein) have very restricted ranges in $\mathrm{Cr} /(\mathrm{Cr}+$ $\mathrm{Al})$ and $\mathrm{Fe}^{2+} /\left(\mathrm{Fe}^{2+}+\mathrm{Mg}\right)$, as illustrated in Figure 2, as does the main group of magnesiochromite at Finsch (the Finsch suite also contains several Cr-poor outliers). Other suites in the same region have similarly restricted ranges in $\mathrm{Cr} /(\mathrm{Cr}+\mathrm{Al})$, but have higher average values of $\mathrm{Fe}^{2+} /\left(\mathrm{Fe}^{2+}+\mathrm{Mg}\right)$ (e.g., Balmoral, owing to few $\mathrm{Mg}-$ rich grains, Lace, with its anomalous Fe-rich population, and Star and Bobbejaan, with slightly more Fe-rich populations). In contrast, at Liqhobong and Kao, in Lesotho on the southeast margin of the Kaapvaal Craton, Jwaneng in the northwest region of the Kaapvaal Craton and the two Botswana pipes (Orapa and Letlhakane) on the Zimbabwe Craton, aluminian magnesiochromite is much more prominent (Fig. 2).

The fertility of these five suites, and that of the more centrally located Loxtonsdal kimberlite, which is similarly Al-rich, and anomalously so for its location, may be due to retention of primary fertility (that is, the peridotite has not been as severely depleted in magmatophile elements as most of the subcratonic Kaapvaal lithosphere) or "re-fertilization" by later

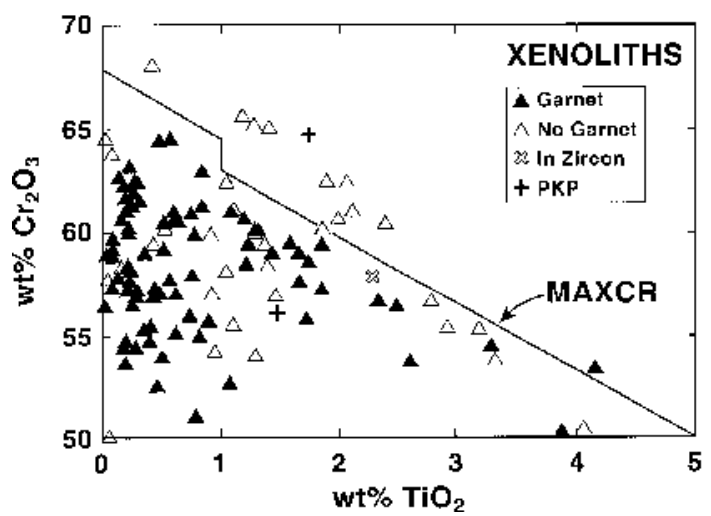

FIG. 12. $\mathrm{Cr}-\mathrm{Ti}$ variations in composition of chromian spinel from xenoliths in this study. The line labeled MAXCR, from Grutter \& Apter (1998), represents the upper compositional limit of chromian spinel that coexists with garnet. 
magmas or fluids has occurred. An origin through such refertilization processes has been proposed for fertile peridotites from the Colorado-Wyoming kimberlite province by Eggler et al. (1987b).

Pearson et al. $(1995,1998)$ and Carlson et al. (1998) have shown that the Re-Os model of age of depletion of magmaphilic elements in lithospheric peridotites from southern Africa kimberlites varies in concert with the age of the basement through which the kimberlites were intruded. Xenoliths from the Kaapvaal Craton, of Archean age, yielded Archean Re-Os depletion ages (with those from Lesotho being the oldest), whereas those from Proterozoic mobile belts to the west (Namibia) and east (East Griqualand) have Proterozoic depletion ages. As the Lesotho Liqhobong "spinel" suite is the most fertile in this study, there is no positive correlation between age of depletion and degree of depletion. Alternatively, if low $\mathrm{Cr} /(\mathrm{Cr}+\mathrm{Al})$ values of "spinel" suites are due to refertilization, the enrichment processes may not be reflected in Re-Os depletion ages.

The apparent difference of the two "spinel" suites from the Zimbabwe Craton, relative to the main Kaapvaal Craton cluster, is intriguing. It may be that the Zimbabwe cratonic mantle is distinctly different (more aluminous or fertile) than that of the Kaapvaal Craton. The close similarity of the Jwaneng suite to those of Orapa and Letlhakane suggests that the lithospheric mantle in the northwestern portion of the Kaapvaal Craton is as fertile as that of the Zimbabwe Craton. Clearly, more "spinel" suites from key localities, providing more thorough geographic coverage in southern Africa, must be studied to evaluate such possibilities.

The low- $\mathrm{Cr} /(\mathrm{Cr}+\mathrm{Al})$ nature of the Loxtonsdal macrocryst suite (Fig. 2) also is anomalous, being located in the middle of the Al-depleted portion of the Kaapvaal Craton (Fig. 1). The absence of mantle xenoliths from this locality will make it difficult to unravel the cause of this geochemically anomalous region of the Kaapvaal Craton mantle.

\section{Conclusions}

Virtually all of the single-crystal macrocrysts of spinel-group minerals that occur in kimberlites in southern Africa are interpreted to be xenocrysts, derived by disaggregation of mantle peridotites (primarily garnetbearing varieties). Most of the suites in this study are dominated by magnesiochromite compositions in the range $0.80<\mathrm{Cr} /(\mathrm{Cr}+\mathrm{Al})<0.90$ and $0.30<\mathrm{Fe}^{2+} /\left(\mathrm{Fe}^{2+}\right.$ $+\mathrm{Mg})<0.50$. This is also the compositional range of most spinel-group minerals in depleted peridotite, the products of magmatic depletion from a hypothetical "primary fertile" peridotite.

Spinel compositions with lower $\mathrm{Cr} /(\mathrm{Cr}+\mathrm{Al})$ values, typically trending along a line indicating equilibrium with $\mathrm{Mg}$-rich peridotite (approximately $\mathrm{Fo}_{90}$ ), are xenocrysts from less strongly depleted peridotite. Such peridotite may retain some of its primary fertility, or be the product of interaction of depleted peridotite and more recently introduced contaminating ("refertilizing") magmas or fluids. Extremely low values of $\mathrm{Cr} /(\mathrm{Cr}+\mathrm{Al})$ $(<0.01)$ are uncommon in the southern African "spinel" population in this study, but some do occur and may suggest the presence of disaggregated pyroxenites or alkremites (garnet-spinel rocks).

Metasomatic processes (interaction with incompatible-element-rich magmas or fluids) also deplete chromian spinel in $\mathrm{Al}$ [the partitioning of $\mathrm{Al}$ into phlogopite increases $\mathrm{Cr} /(\mathrm{Cr}+\mathrm{Al})$ of the coexisting chromian spinel], and may introduce titanium. Ti-enrichment (2$4 \mathrm{wt} \% \mathrm{TiO}_{2}$ ) in Al-depleted chromian spinel macrocrysts $[\mathrm{Cr} /(\mathrm{Cr}+\mathrm{Al})>0.88]$ is more common in examples from Group-I kimberlites than Group-II suites, a phenomenon that is not understood at present. Chromite that is the product of extreme metasomatism, such as that occurring in metasomatized phlogopite potassic richterite - LIMA peridotites and as inclusions in mantle-derived zircon, is rare in the macrocryst suite. Further documentation of the compositions of chromian spinel in metasomatized peridotites is needed to understand the origin of the very $\mathrm{Cr}$-rich chromite macrocrysts.

Several anomalies in "spinel" composition occur in the mantle sampled by kimberlites examined in this study. The mantle appears more aluminous beneath Lesotho (e.g., Liqhobong), on the southwestern margin of the Kaapvaal Craton, and beneath the Zimbabwe Craton to the north (Orapa and Letlhakane), as well as in the centrally located Loxtonsdal kimberlite. A unique population of Fe-rich chromite occurs in the Lace kimberlite, which may have an origin related to 2020 Ma Vredefort meteorite impact-related processes that affected the mantle to depths of at least 150 kilometers.

\section{ACKNOWLEDGEMENTS}

This contribution to the petrological aspects of spinel-group minerals is dedicated to Pete Roeder. It is a privilege to be included among those invited to contribute to this volume in his honor. This study would not have been possible without the ongoing assistance of De Beers and Anglo American Research personnel, especially Barry Hawthorne, Roger Clement, John Bristow, Mike Skinner, Alex van Zyl, Fanus Viljoen, Jock Robey, George Reid, Mike McGurl, Herman Grutter, and others. Assistance was also provided by David Bell, Claudio Cermignani and owners of the various mines from which I obtained samples. I also thank Herman Grutter and Desmond Moser for useful input and discussions on various aspects of this study. The reviews of this manuscript provided by Dante Canil, Herman Grutter and Bob Martin improved its quality. Financial support was provided by NSERC. My sincere thanks go to all. 


\section{REFERENCES}

ARAI, S. (1994): Characterization of spinel peridotites by olivine-spinel compositional relationships: review and interpretation. Chem. Geol. 113, 191-204.

Ayres, N.P., Hatton, C.J., Quadling, K.E. \& Smith, C.B. (1998): Update on the Distribution in Time and Space of Southern African Kimberlites (map). De Beers Geoscience Centre, Johannesburg, South Africa.

BOYD, F.R. \& NIXON, P.H. (1973): Origin of the ilmenite-silicate nodules in kimberlites from Lesotho. In Lesotho Kimberlites (P.H. Nixon, ed.). Lesotho National Development Corporation, Maseru, Lesotho (254-268).

\section{\&}

(1978): Ultramafic nodules from the Kimberley pipes, South Africa. Geochim. Cosmochim. Acta 42, 1367-1382.

, Pearson, D.G. \& Mertzman, S.A. (1999): Spinelfacies peridotites from the Kaapvaal root. In The J.B. Dawson Volume - Proc. VII ${ }^{\text {th }}$ Int. Kimberlite Conf. 1 (J.J. Gurney, J.L. Gurney, M.D. Pascoe \& S.R. Richardson, eds.). Red Roof Design, Cape Town, South Africa (40-48).

Brey, G.P., Doroshev, A. \& Kogarko, L. (1991): The join pyrope-knorringite: experimental constraints for a new geothermobarometer for coexisting garnet and spinel. Fifth Int. Kimb. Conf. (Araxa, Brazil), Extended Abstr., 26-28.

Carlson, R.W., Grove, T.L., De Wit, M.J. \& Gurney, J.J. (1996): Program to study the crust and mantle of the Archean craton in southern Africa. Trans. Am. Geophys. Union (Eos) 77, 273, 277.

Pearson, D.G., Boyd, F.R., Shirey, S.B., Irvine, G., MenZies, A.H. \& Gurney, J.J. (1998): Regional age variations of the southern African mantle: significance for models of lithospheric mantle formation. Seventh Int. Kimberlite Conf. (Cape Town), Extended Abstr., 135-137.

Carswell, D.A., Clarke, D.B. \& Mitchell, R.H. (1979): The petrology and geochemistry of ultramafic nodules from Pipe 200, northern Lesotho. In The Mantle Sample: Inclusions in Kimberlites and Other Volcanics. Proc. Second Int. Kimberlite Conf. 2 (F.R. Boyd \& H.O.A. Meyer, eds.). American Geophysical Union, Washington, D.C. (127144).

Griffin, W.L. \& Kresten, P. (1984): Peridotite nodules from the Ngopetseu and Lepelaneng kimberlites, Lesotho: a crustal or mantle origin. In Kimberlites II: The Mantle and Crust-Mantle Relationships (J. Kornprobst, ed.). Elsevier, Amsterdam, The Netherlands (229-243).

Daniels, L.R.M. \& GuRneY, J.J. (1989): The chemistry of the garnets, chromites and diamond inclusions from the Dokolwayo kimberlite, Kingdom of Swaziland. In Kimberlites and Related Rocks. 2. Their Mantle/Crust Setting, Diamonds and Diamond Exploration (J. Ross, ed.). Blackwell, Carlton, Australia (1012-1021).
Dawson, J.B. \& Smith, J.V. (1975): Chromite-silicate intergrowths in upper mantle peridotites. Phys. Chem. Earth 9, 339-350.

DE Wit, M.J., Roering, C., Hart, R.J., Armstrong, R.A., DE Ronde, C.E.J., Green, R.W.E., Tredoux, M., Peberdy, E. \& HART, R.A. (1992): Formation of an Archean continent. Nature 357, 553-562.

Doroshev, A.M., Brey, G.P., Girnis, A.V., Turkin, A.I. \& Kogarko, L.N. (1997): Pyrope-knorringite garnets in the Earth's mantle: experiments in the $\mathrm{MgO}-\mathrm{Al}_{2} \mathrm{O}_{3}-\mathrm{SiO}_{2}-$ $\mathrm{Cr}_{2} \mathrm{O}_{3}$ system. Russian Geol. Geophys. 38, 559-586.

EgGler, D.H., Dudas, F.O., Hearn, B.C., JR., McCallum, M.E., McGee, E.S., Meyer, H.O.A. \& Schulze, D.J. (1987b): Lithosphere of the continental United States: xenoliths in kimberlites and other alkaline magmas. In Mantle Xenoliths (P.H. Nixon, ed.). John Wiley \& Sons, London, U.K. (41-57).

McCallum, M.E. \& Kirkley, M.B. (1987a): Kimberlite-transported nodules from Colorado-Wyoming: a record of enrichment of shallow portions of an infertile lithosphere. In Mantle Metasomatism and Alkaline Magmatism (E.M. Morris \& J.D. Pasteris, eds.). Geol. Soc. Am., Spec. Pap. 215, 77-90.

Erlank, A.J., Waters, F.G., Hawkesworth, C.J., Haggerty, S.E., Allsopp, H.L., Rickard, R.S. \& Menzies, M.A. (1987): Evidence for mantle metasomatism in peridotite nodules from the Kimberley pipes, South Africa. In Mantle Metasomatism (M.A. Menzies \& C.J. Hawkesworth, eds.). Academic Press, San Diego, California (221-311).

FInNeRTY, A.A. \& BoYD, F.R. (1987): Thermobarometry for garnet peridotites: basis for the determination of thermal and compositional structure of the upper mantle. In Mantle Xenoliths (P.H. Nixon, ed.). John Wiley \& Sons, New York, N.Y. (381-402).

FiPKe, C.E., Gurney, J.J. \& Moore, R.O. (1995): Diamond exploration techniques emphasising indicator mineral geochemistry and Canadian examples. Geol. Surv. Can., Bull. 423.

GIRNIS, A.V. \& BREY, G.P. (1999): Garnet - spinel - olivine orthopyroxene equilibria in the $\mathrm{FeO}-\mathrm{MgO}-\mathrm{Al}_{2} \mathrm{O}_{3}-\mathrm{SiO}_{2}-$ $\mathrm{Cr}_{2} \mathrm{O}_{3}$ system. II. Thermodynamic analysis. Eur. J. Mineral. 11, 619-636.

Griffin, W.L., Ryan, C.G., Gurney, J.J., Sobolev, N.V. \& WIN, T.T. (1994): Chromite macrocrysts in kimberlites and lamproites: geochemistry and origin. In Kimberlites, Related Rocks and Mantle Xenoliths (H.O.A. Meyer \& O.H. Leonardos, eds.). Companhia de Pesquisa de Recurcos Minerais, Brasilia, Brazil (366-367).

Grutter, H.S. \& Apter, D.B. (1998): Kimberlite- and lamproite-borne chromite phenocrysts with "diamond-inclusion" type chemistries. Seventh Int. Kimberlite Conf. (Cape Town), Extended Abstr., 280-282. 
Gurney, J.J., Helmstaedt, H. \& Moore, R.O. (1993): A review of the use and application of mantle mineral chemistry in diamond exploration. Pure and Appl. Chem. 65 , 2423-2442.

\& MoORE, R.O. (1993): Geochemical correlations between kimberlite indicator minerals and diamond. In Diamonds: Exploration, Sampling and Evaluation. Prospectors and Developers Association of Canada Short Course (141-171).

HAGGERTY, S.E. (1983): The mineral chemistry of new titanates from the Jagersfontein kimberlite, South Africa: implications for metasomatism in the upper mantle. Geochim. Cosmochim. Acta 47, 1833-1854.

(1991): Oxide mineralogy of the upper mantle. In Oxide Minerals: Petrologic and Magnetic Significance (D.H. Lindsley, ed.). Rev. Mineral. 25, 355-416.

Hervig, R.L., Smith, J.V., Steele, I.M. \& Dawson, J.B. (1980): Fertile and barren Al-Cr spinel harzburgites from the upper mantle: ion and electron probe analyses of trace elements in olivine and orthopyroxene: relation to lherzolites. Earth Planet. Sci. Lett. 50, 41-58.

IRVINE, T.N. (1965): Chromian spinel as a petrogenetic indicator. I. Theory. Can. J. Earth Sci. 2, 648-672.

(1967): Chromian spinel as a petrogenetic indicator. II. Petrologic applications. Can. J. Earth Sci. 4, 71-103.

Mazzone, P. \& Haggerty, S.E. (1989): Corganites and corgaspinites: two new types of aluminous assemblages from the Jagersfontein kimberlite pipe. In Kimberlites and Related Rocks. 2. Their Mantle/Crust Setting, Diamonds, and Diamond Exploration. (J. Ross, ed.), Blackwell, Carlton, Australia (795-808).

McCallum, M.E. \& Waldman, M.A. (1991): The diamond resources of the Colorado-Wyoming State Line District: kimberlite indicator mineral chemistry as a guide to economic potential. Wyoming Geol. Assoc., Forty-second Field Conf., Guidebook, 77-90.

Meyer, H.O.A. (1987): Inclusions in diamond. In Mantle Xenoliths (P.H. Nixon, ed.). John Wiley \& Sons, Chichester, U.K. (501-522).

Mitchell, R.H. (1995): Kimberlites, Orangeites, and Related Rocks. Plenum Press, New York, N.Y.

\& ClARKE, D.B. (1976): Oxide and sulphide mineralogy of the Peuyuk kimberlite, Somerset Island, N.W.T., Canada. Contrib. Mineral. Petrol. 56, 157-172.

Moser, D.E. (1997): Dating the shock wave and thermal imprint of the giant Vredefort impact, South Africa. Geology 25, 7-10.

\& HART, R.J. (1998): Neoarchean and Paleoproterozoic re-activation of the crust-mantle transition beneath the central Kaapvaal craton, Lace kimberlite. Seventh Int. Kimberlite Conf. (Cape Town), Extended Abstr., 609-611.
\& FlOWERS, R. (1999): Impact-triggered deep-seated magmatism beneath the Vredefort structure, South Africa. Trans. Am. Geophys. Union (Eos) 80, 595 (abstr.).

O'Neill, H.St.C. (1981): The transition between spinel lherzolite and garnet lherzolite, and its use a geobarometer. Contrib. Mineral. Petrol. 77, 185-194.

Pearson, D.G., Carlson, R.W., Boyd, F.R., Shirey, S.B. \& NiXON, P.H. (1998): Lithospheric mantle growth around cratons: a Re-Os isotope study of peridotitic xenoliths from East Griqualand. Seventh Int. Kimberlite Conf. (Cape Town), Extended Abstr., 658-660.

, SHIREY, S.B., BOYd, F.R. \& NiXON, P.H. (1995): Stabilization of Archean lithospheric mantle: a ReOs isotope study of peridotite xenoliths from the Kaapvaal craton. Earth Planet. Sci. Lett. 134, 341-357.

Roeder, P.L. (1994): Chromite: from the fiery rain of chondrules to the Kilauea Iki lava lake. Can. Mineral. 32, 729-746.

Schulze, D.J. (1990): Silicate-bearing rutile-dominated nodules from South African kimberlites: metasomatized cumulates. Am. Mineral. 75, 97-104.

(1996): Chromite macrocrysts from southern African kimberlites: mantle xenolith sources and post-diamond re-equilibration. Africa Geosci. Rev. 3, 203-216.

\& Helmstaedt, H. (1988): Coesite-sanidine eclogites from kimberlite: products of mantle fractionation or subduction? J. Geol. 96, 435-443.

Valley, J.W., Viljoen, K.S., Stiefenhofer, J. \& SpICUZZA, M. (1997): Carbon isotope composition of graphite in mantle eclogites. J. Geol. 105, 379-386.

Smith, C.B. (1983): $\mathrm{Pb}, \mathrm{Sr}$, and $\mathrm{Nd}$ isotope evidence for sources of southern African Cretaceous kimberlites. $\mathrm{Na}$ ture 304, 51-54.

Tollo, R.P. \& HaggerTy, S.E. (1987): Nb-Cr-rutile in the Orapa kimberlite, Botswana. Can. Mineral. 25, 251-264.

Vicker, P.A. (1997): Garnet Peridotite Xenoliths from Kimberlite near Kirkland Lake, Canada. M.Sc. thesis, Univ. of Toronto, Toronto, Ontario.

Wyatt, B.A., Shee, S.R., Griffin, W.L., Zweistra, P. \& Robison, H.R. (1994): The petrology of the Cleve kimberlite, Eyre Peninsula, South Australia. In Kimberlites, Related Rocks and Mantle Xenoliths (H.O.A. Meyer \& O. Leonardos, eds.). Companhia de Pesquisa de Recursos Minerais, Brasilia, Brazil (62-79).

Received March 15, 2000, revised manuscript accepted March 30, 2001. 